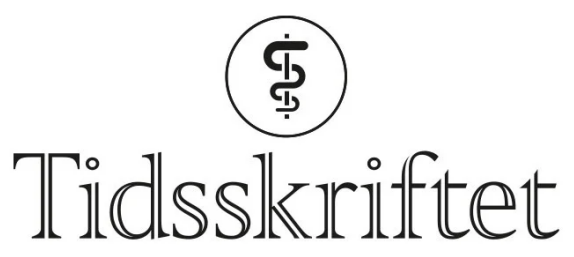

DEN NORSKE LEGEFORENING

\title{
Justering av p-verdier på norsk
}

SPRÅKSPALTEN

STIAN LYDERSEN

stian.lydersen@ntnu.no

Stian Lydersen er dr.ing. og professor i medisinsk statistikk ved Regionalt kunnskapssenter for barn og unge - psykisk helse og barnevern (RKBU Midt-Norge) ved Institutt for psykisk helse, NTNU. Forfatteren har fylt ut ICMJE-skjemaet og oppgir ingen interessekonflikter.

\section{Familievis feilrisiko og falsk deteksjonandel er forslag til oversettelser av engelskspråklige faguttrykk ved testing av multiple hypoteser.}

Medisinsk statistikk er full av engelskspråklige faguttrykk. Mange av dem har gått uendret inn i norsk fagspråk, mens andre har fått norske avløserord.

Familywise error rate, ofte forkortet FWER, og false discovery rate, forkortet FDR, er to faguttrykk som jeg ikke har sett omtalt i norske lærebøker i statistikk. De er relevante når man skal foreta flere hypotesetester i samme studie, slik som forklart i en artikkel i dette nummeret av Tidsskriftet (1). Kort fortalt så er familywise error rate sannsynligheten for å feilaktig forkaste minst én sann nullhypotese, altså å gjøre minst én type I-feil, dvs. minst ett falskt positivt funn (므). False discovery rate er forventet andel type I-feil, dvs. andel falskt positive funn blant de nullhypotesene som forkastes $(\underline{1}, \underline{2})$.

Metoder for å justere for multiple hypoteser blir sjelden omtalt i grunnleggende lærebøker i statistikk. Jeg har heller ikke funnet norske termer i lærebøker i forskningsmetodikk eller i Store norske leksikon. Hva kan være passende norske termer for disse begrepene? Jeg spurte noen norske statistikere, og fikk følgende forslag:

Familywise error rate - familievis feilrate, familievis feilandel, familievis feilrisiko

False discovery rate - falsk deteksjonsrate, falsk deteksjonsandel, falsk deteksjonsrisiko

Alle disse forslagene er etter mitt syn gode, og de har ulike fordeler og ulemper. De to førstnevnte forslagene ligger nærmest opp til det engelske rent språklig, hvilket er en fordel. Termen rate brukes av og til på norsk i betydningen 'andel', som er et mer vanlig norsk ord i denne sammenheng. Men familywise error rate er sannsynligheten for minst ett falskt positivt funn, hvilket ikke er en andel. Risiko er et godt innarbeidet norsk ord for sannsynlighet for uønskede hendelser. Derfor er familievis feilrisiko etter mitt syn en god norsk term for familywise error rate. 
Ved false discovery rate aksepterer man en viss andel falskt positive funn, vanligvis inntil $5 \%$, blant de funnene som deklareres som positive. Falsk deteksjonsandel er derfor etter mitt syn en god norsk term for false discovery rate.

Takk til Geir Egil Eide og Are Hugo Pripp for nyttige innspill.

\section{LITTERATUR}

1. Lydersen S. Justering av p-verdier ved multiple hypoteser. Tidsskr Nor Legeforen 2021; 141. doi: 10.4045/tidsskr.21.0357. [CrossRef]

2. Lydersen S. Type I-feil og type II-feil. Tidsskr Nor Legeforen 2021; 141. doi:10.4045/tidsskr.21.0013. [PubMed][CrossRef]

Publisert: 27. september 2021. Tidsskr Nor Legeforen. DOI: 10.4045/tidsskr.21.036o

(C) Tidsskrift for Den norske legeforening 2023. Lastet ned fra tidsskriftet.no 26. april 2023. 